\title{
Recommendation of Knockdown Building Design at Yogyakarta Sand Dunes (Restricted and Heritage Areas)
}

\author{
ADWITYA BHASKARA, FITRI NUGRAHENI, FARIED HANAFI
}

\begin{abstract}
Sand dunes located in Special Region of Yogyakarta Indonesia is a restricted caused by the heritage and there only four spread in hemisphere one of them in Yogyakara, Indonesia. To build in sand dunes area building could not be built arbitrarily. Portable and knockdown is the character of the building that could be adjust to the conditions in Sand dunes. By the observation results compact building design with cold formed steel material for the main building material is the recommendation of this case. The design is then consulted with sub-contractors who are expert in their expertise as the validation stage, it is feasible to be transformed into a real building for the specific needs. Output of this research is recommendation of portable building model in modular form, where the design recommendation has been adjusted with building requirement in heritage and restricted area, which is also an area prone to tsunamis and wind disasters, therefore the recommended building are; easy to remove, easy to disassemble (knockdown), forward tsunami load, efficient cost and time (using cold formed steel material and prefabricated GRC), eco friendly (zero waste), does not require many workers (less man power).
\end{abstract}

Keywords: construction management, heritages, implementation method, knockdown, sand dunes, restricted

\section{INTRODUCTION}

Indonesia is one of four countries in the world that has a sand dune phenomenon. Sand dune is geomorphological unit caused by wind activity (eolian). The contour of the sand dune itself alternates with what is called a swale, which is landscape that is basin between two dunes. The sand dune and swale as overall form a wavy relief consisting of loose sand material consisting of loose sand material. Coastal area with ramps morphological, loose sand material, and sand tend to be straight and long usually found many dunes. With the coastal morphology, and supported by wind activity affecting sea surface waves, it is possible that the sand dunes and surrounding areas are vulnerable to relatively high tsunami waves (Marwasta and Priyono, 2016). In Indonesia, the only sand dunes are located in Parangtritis area, Kretek sub district, Bantul, Yogyakarta. According to several studies, Parangtritis coastal areas including as tsunami prone areas and the surrounding sand dunes are heritage area, its protected by the Yogyakarta government. In this area we unable to build at random, there are particular regulations to build buildings in heritage area.

One of force majeure is tsunami disaster. "A tsunami is accompanied by severe earthquake, but the earthquake does not cause the tsunami. Rather, both are caused by the same sudden crustal displacement (Mcdonald, 1946). Tsunami disaster usually occurs after the earthquake, but according to Macdonald (1946) earthquake is not always the cause of the arrival of the tsunami, and vice versa. Tsunamis and earthquakes occur due to significant plates / crust extension. We know that some provinces in Indonesia are vulnerable areas. As one example of the tsunami disaster in Aceh on December 26, 2004 ago. Indonesia is an area prone to earthquakes because it is traversed by the path of meeting three tectonic plates of the Indo-Australian plate, Eurasian plate, and the Pacific plate. For the potential tsunami disaster, Indonesia ranks first in 265 countries in the world surveyed by the UN agency. The risk of 
tsunami threats in Indonesia is even higher than in Japan.

The tsunami was the result of a very large undersea earthquake, where the Earth's crust had split like a zipper along an extensive fault line, starting near Sumatra and reaching a thousand kilometres northward into the Bay of Bengal. With some shock, the public learned that geologists and seismologists were well aware of the fault and had warned that massive forces built up over hundreds of years could unleash earthquakes and tsunamis at any time. Some scientists had argued for an Indian Ocean tsunami warning system, mirrored on the longestablished Pacific Ocean tsunami warning system, but to no avail (Koltermann, 2009).

With the existing conditions in Indonesia, it is necessary adjustment in establishing a particular building, especially in tsunami prone areas.

One of the dunes in Indonesia is located in Bantul district of DIY. In relation to the condition of the dune location as described in the above paragraph, most of the coastal sand dunes in Bantul DIY are "heritage areas" where we are prohibited from constructing buildings in the area. although this area has only a small tsunami potential, a building erected on this coastal dune will remain at risk of damage. this condition is of course one of the risks of force majeure from the construction of a construction project, so as a form of mitigation, the planned buildings to be built on the slopes of Bantul, DIY should be able to withstand the small threat of tsunami.

Easy-to-move and portable buildings are one of the alternative building models for this potentially tsunami-prone restricted area. When needed this building could be arranged, and could be dismantled after not used like a Lego / knockdown system.

Currently in Indonesia there is already a knockdown building system called RISHA (Simple Healthy Instant Home). The RISHA system is a precast system construction technology for simple buildings using knockdown systems, consisting of modular components made by fabrication. Knock Down House (assembly) and instant is effective and efficient, so that when the assembly in the field there is no need for modifications and casting of its components (Subrata, 2013).
In addition to the advantages, this system also has deficiency, i.e. not fully fabricated on the foundation, so RISHA has not answered the DIY government's need for flexible knockdown building in Yogyakarta Sand Dunes.

Different from concrete, steel is lighter and its more possibly to carried around (portable). Other than that, the knockdown also could be applied as well to steel material. Steel is a material that adequately meets the criteria and needs of the government that is effective, efficient and can adjust to the conditions in the sand dune Parangtritis. With that condition, also the pre-eminence of the steel material, the steel material is the material chosen in this study, as it adequately meets the needs of the government.

Show on Figure 1 the problem statement in this research that Yogyakarta Sand Dunes are restricted area due to the potential of small tsunamis and wind disaster, moreover Yogyakarta Sand Dunes are heritage, without regulations and permission then any buildings unable to build in that area.

Purposes in this research is recommends a portable building design which easy to install and dismantle where the properties of are adjusted to the needs, conditions and requirements of building construction in Yogyakarta Sand Dunes.

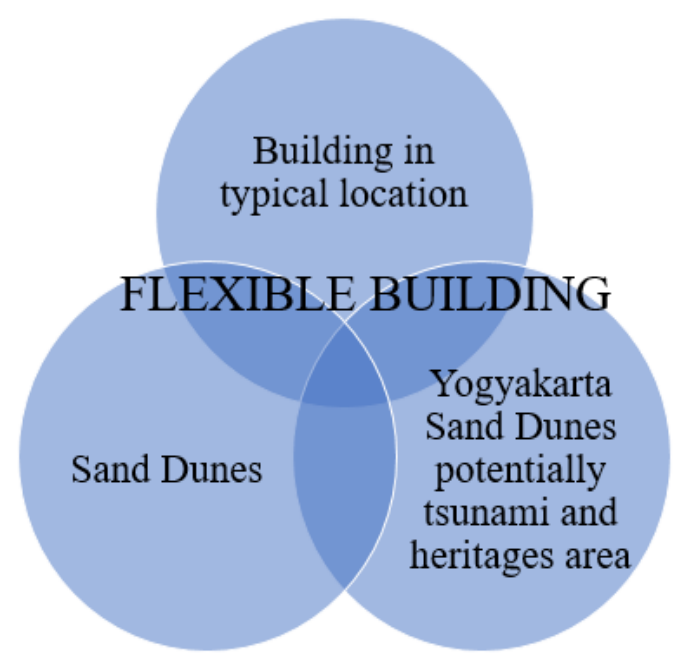

FIGURE 1. llustration of Problem Statement 


\section{RESEARCH METHOD}

The research process begins with finding and recognizing problems that exist, based on literature review conducted it was found that to establish a portable building on this sand dunes must be adjusted to the conditions and regulations of the government.

This type of research is building system modelling. The model is a portable building planning design that could explain the object in representative and descriptive. While the system is a unity consisting of components or elements that are sustainable. Thus, the modelling system in this research is the design of the design in the form of images to facilitate the understanding of the required information.

\section{Research Stages}

Research data divided into two, namely primary and secondary data. The primary data are as follows:

a. Instance Survey

b. Site survey

c. Literature Review

Secondary data in this study was obtained by collecting documents related to the implementation of activities, both in the form of reports and records of related institutions, data photos / pictures / maps.

\section{RESULT AND DISCUSSION}

The research process begins with finding and knockdown system allows to adjust the needs of the building area according to the module. The modular buildings are created in modules per 4 meters.
In this study the recommended steel type for structure is cold formed steel. This type of steel is chosen because it is flexible (strong, easy, and fast in installation and dismantling). This type of steel is also resistant to rust (there is a layer of anti-rust) and has been proven in salt pre-test. For roof cover used galvalum. Galvalum contains more zinc then it is more resistant to salinity in coastal area. In addition to the bright colour of the galvalum can reflect sunlight, thus could minimize the heat of sunlight into the building.

As for the wall using GRC. This material is chosen because in addition to its fairly efficient price, the GRC is also quite vulnerable to tsunami waves, in other words the recommendations on the walls of this building are deliberately designed with weak materials that could be destroyed when exposed to the tsunami, so that tsunami currents can continue through the building framework as described in the Design Guidelines for the Evaluation of Tsunami Vertical Structures (FEMA P646, 2008). The foundation may use conventional foundations or also the use of precast foundations in the form of concrete blocks. However, in this research, it is recommended to use precast foundation because it is suitable with semi-permanent building concept

\section{P.E.B Recommendation}

In the consultation process to the experts, the steel frame structure has been recommended using the P.E.B system. Pre Engineering Building (P.E.B) is a new construction technology commonly applied with cold formed steel materials where the building be able to sturdy and strong building structure with very fast and efficient construction time. Perspective Modular Building Frame by P.E.B shown in Figure 2.

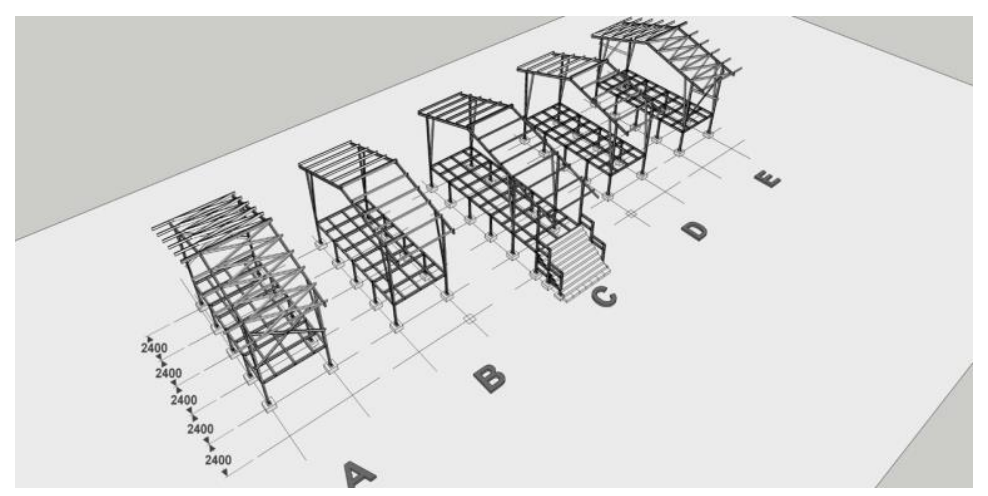

FIGURE 2. Perspective Modular Building Frame 
The steel frame structure has been recommended using the P.E.B system. Pre Engineering Building (P.E.B) is a new construction technology commonly applied with cold formed steel materials where the building be able to sturdy and strong building structure with very fast and efficient construction time.

In support of strength, security and architecture there are several preferred components of the P.E.B system as follows:

a) Main frame rafter

b) Strut beam

c) Roof bracing

d) Purlin

e) Sag Rod

f) Jamb door

g) Window frame

h) Girt

i) Wall Bracing

j) Bridging

One of the most important parts of the PEB structure is the use of appropriate connectors. So that PEB structure able to bear the load in accordance with the mensuration before.

The steel material used standard with a minimum yield strength of $450 / 550 \mathrm{Mpa}$, Minimum tensile stress 450/550 Mpa, modulus of elasticity of 200,000 Mpa, and using Hot Dip Galvanized Z220 and Z275 stainless coating.
In the mensuration of the PEB structure using a system computed with certain standards, in the mensuration of wind codes ASCE 207-05, on Earth quake SKSNI 1726 - 2002 and UBC 1997. Design codes using AISI 1996 and 2001 and Design Load using Indonesia Load Rules 1970, ASCE 2005, and MBMA 2002.

The modular building is designed to be a single unit. For size able adjust according to requirements. Figure 3 . is an example of building design which is a composite of some modular.

Floor framework connections in semipermanent buildings are planned to use steel with a $150 \mathrm{~mm}$ profile width connected to a column profile that also serves as a pedestal with a width of $140 \mathrm{~mm}$. The floor framework profile has a distance of $430 \mathrm{~mm}$ to baseplat. For connection of column profile to baseplate plate used plate with same material with height $167,5 \mathrm{~mm}$ and thickness 3 to $10 \mathrm{~mm}$ with 12 bolts to strengthen the connection. Baseplate measuring $250 \times 360 \mathrm{~mm}$, attached to precaast foundation. Baseplate connected to the foundation uses a chemical anchor and bolts as many as 6 pieces without welding work. The bolts used for connections with a diameter of $12.7 \mathrm{~mm}$ have a power of $129 \mathrm{Nm}$, with a diameter of $15.9 \mathrm{~mm}$ having a rotating power of $258 \mathrm{Nm}$, with a diameter of $19.1 \mathrm{~mm}$ having a rotational power of $454 \mathrm{Nm}$, with varying lengths from 35 to $55 \mathrm{~mm}$

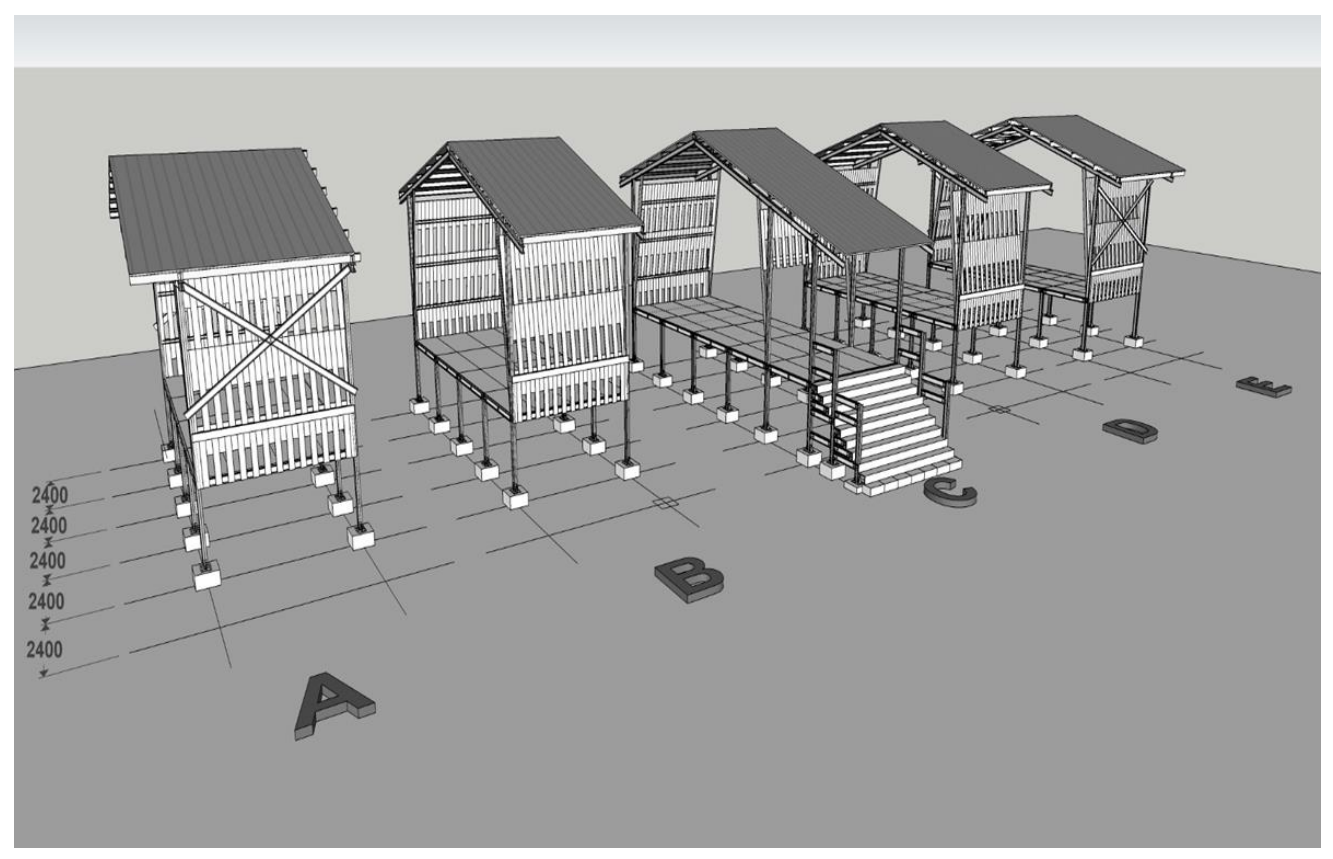

FIGURE 3. Perspective Modular Building 
The recommended foundation is $600 \times 600 \times$ $600 \mathrm{~mm}$ with concrete material with $20 \mathrm{mPa}$ spek. To transport the precast foundation could be done by using a forklift whose trajectory is given plywood or plywood so that the heavy equipment used by the wheel does not sink. The foundation is planned to be opened at a height of $100 \mathrm{~mm}$ from the ground to increase the elevation of the building (Nugraheni et al, 2008). Combination of Modular Building shown in following Figure 4.

\section{Location Plan}

This building is recommended to be built in Sand Dunes area. In Indonesia this building is recommended in Parangtritis Tourist Area around sand dunes located between Parangtritis Beach and Depok Beach. This location is administratively located in Parangtritis Village, Kretek Subdistrict, Bantul Regency.

\section{Legal Base}

Legal base on recommendation of knockdown building at Yogyakarta Sand Dunes:

1. Law No. 5 of 1990 on the Conservation of Natural Resources and Ecosystems
2. Regional Regulation D.I. Yogyakarta No. 4 of 2015 on Conservation of Nature.

3. Governor Regulation D.I. Yogyakarta Number 115 of 2015 on the Preservation of Geological Heritage Area

Regarding to the planning of religious tourism building in this study, in accordance with the research conducted by the Geospatial Information Agency (BIG) in cooperation with the Faculty of Geography UGM, thus has been formed the zonation area composition of sand dunes in the context of education, research and conservation of sand dune is part of a natural process sequence integrated in a very harmonious stage.

Based on the conclusions of regulations above, the sand dune is a prone area and protected, therefore building unable be established arbitrarily. The buildings to be built in the sand dunes should be adjusted to government regulations, one of them semi-permanent, as well as tsunami-friendly, so that in the event of a tsunami these buildings can still be established, of course with the damage that has been planned in accordance with the mensuration.

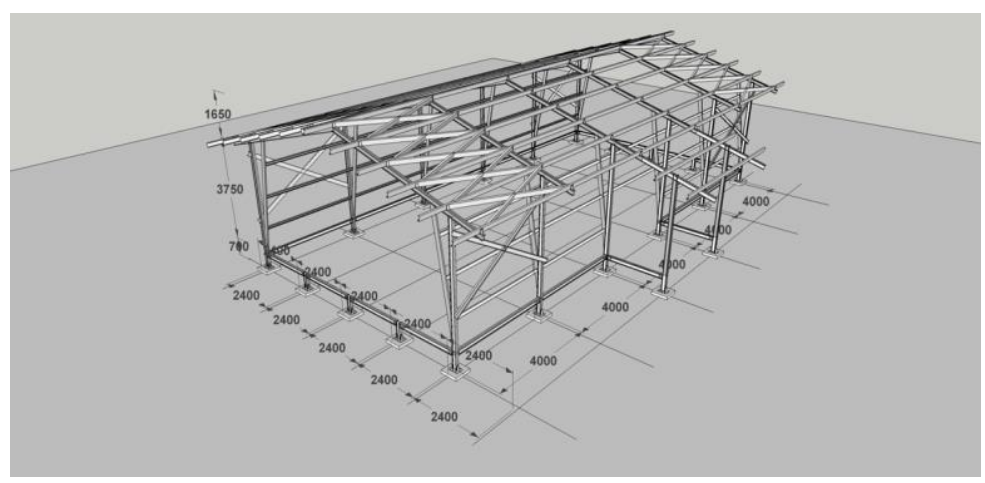

FIGURE 4. Combination of Modular Building

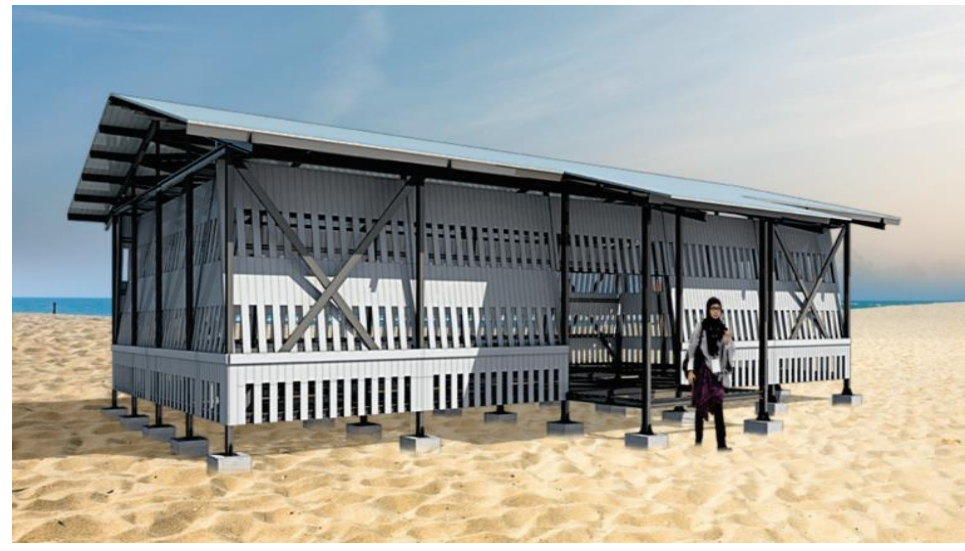

FIGURE 5. Combination of Modular Building (Animation) 


\section{Building Requirements}

Hazards comprehension based on Coburn (1994) in the following covers:

1. How those hazards arise

2. Possibility and magnitude

3. Damage physical mechanism

4. Susceptible elements and activities towards the effect.

5. Damages consequences

Effective and efficient are the main factors in providing semi-permanent building design recommendations in this study. Thus, cold formed steel is the main material chosen to be recommended. Steel materials are selected by their multiform nature (McCormac, 1981) among others:

1) The ability to be tied together by many elements with simple connections such as bolts and rivets.

2) Easy to fabricate.

3) Easy to Install.

4) Suspension to fatigue load.

5) Reused.

6) Steel structures are combinations designed to withstand loads and provide adequate stiffness (Zhao, 2016).

According to Irwan et al (2016), UNHCR provides portable shelter assistance. Portable occupancy is the right solution because it is cheap, fast, and easy to distribute. However, tents have not met the proper occupancy standards for the refugees. Although Building is the right solution for this. Portable buildings could be cut construction costs and land functions could be as original as possible

Buildings in the sand dunes require to comply definite criteria to obtain the appropriate knockdown building with the planning and meet the recommendation of building properties. The building criteria are as follows:

\section{Flexible Building}

Buildings stands on sand dunes are planned to be dismantled rapidly, thus buildings must be flexible and concise to easily mobile in case of need for site removal or demolition.

2. No work on site

Work on site or is not possible because by regulations explanation that the sand dune is a protected area and prohibit pollution of sand dunes from other materials thus it worried damage the sand material.

3. No heavy equipment

Heavy equipment is not recommended in the sand dunes area, the sand is unstable as machine footing so it caused heavy machinery unable to move or walk on sand and enable heavy equipment to be damaged.

4. Tsunami Friendly

Tsunami friendly buildings means when the tsunami attack building structure keep stand, undamaged or collapsed.

\section{Building Installations}

In the installation process, the first thing to do is to determine the foundation point of the knockdown building. In accordance with the protection regulations of the conservative areas, thus foundation is fabricated outside the sand dune area to keep the sand from being contaminated with cement and damaged. The following are the steps of the installation process of knockdown building.

1. First, the foundation installation is done not by digging the sand, but by put the precast foundation directly on the sand, then the excavation is done from under the foundation by using shovel gradually to get the determined elevation. Next, connecting the column profile to the foundation, conducted by plate support without weld from the baseplate attached of foundation to the column profile.

2. Next setting the column. Profiles of columns used Cold Formed Steel material and conducted by establishing scaffolding in every column. Tighten the anchor bolts and place them on the baseplat.

3. Installation of cross-beams between columns by connecting the bolts with the help of the dial plate.

4. Installation rafter and roof truss in each column point, installation is conduct by using scaffolding. The set profile pulled with scaffolding using the supporting tools. The worker then lifts, then paired right at the column point to install the roof truss.

5. Installation of wall frames shall be carried out thereafter as GRC wall mounting on buildings. According to the mensuration of Cold Formed Steel experts. 
6. The next step continued by install the floor frame of the building with a bolt connection without welding. Workers connect a ready-to-install profile in a building by installing a connecting plate and installing a bolt on the connection. Similarly mounting bracing on the floor frame.

7. Next is the installation of purlin to support the roof of this building.

8. Followed by the installation of roof sheets with galvalum material.

9. The final step is the installation of GRC with thickness $8 \mathrm{~mm}$ to the wall and then on the floor. Then applying bracing as a stiffening structure. Installation of bracing is on the outside wall and below the floor.

Figure 6 is the example of building Installations flowchart for precast foundation.

\section{Uninstall Building}

To support the criteria of building knockdown, in addition to the ease of installation or installation, the building is also required in the demolition.

The uninstall process is conduct by the worker only by removing the bolts on each connection. According to the specialist consultant cold formed steel, the installation process and removing bolt will not damage the building. This is the steps of uninstall knockdown building process.

1. First, the demolition process starts with removing the GRC wall on the building. Uninstall is conduct by removing the bolt on the GRC.

2. Next GRC floor dismantle from the building by removing bolts on GRC.

3. Dismantle of roof sheet or roof of galvalum is done by removing the connection of bolt or screw.

4. Then the roof frame removes from the top of the scaffolding previously installed, the work is done by removing the bolts on the connection at the end of the column. Next the roof truss lowered by supporting tools.

5. The next step is to disconnect the bolts of beam to the column. Then lower the beam with the tools.

6. Followed by dismantling the floor frame. Workers disconnect in each segment by removing bolts from profiles and baseplate.

7. Next disconnect on column bolts. Loosen an anchor and remove the column profile from the baseplat.

8. The last step removes the precast foundation from the ground. lift with forklifts.

Figure 7 is the example of uninstallation building flowchart for precast foundation.

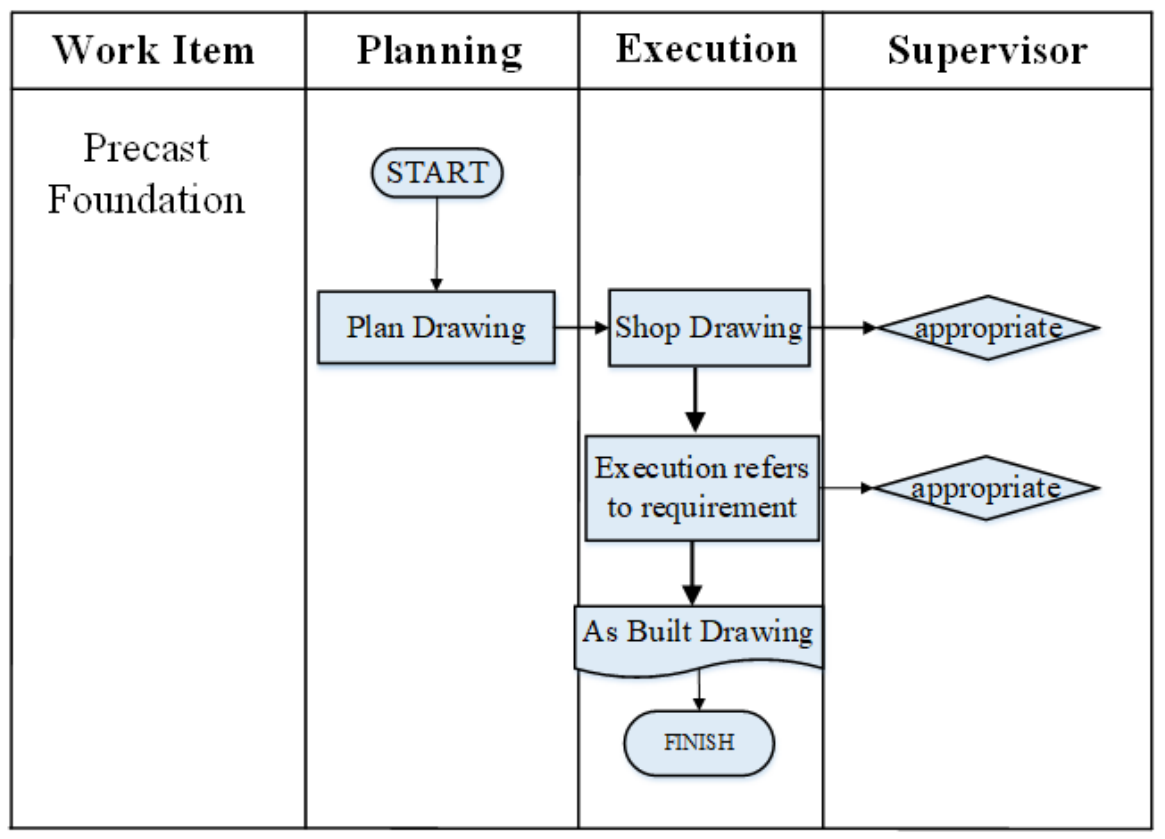

FIGURE 6. Building Installations flowchart for precast foundation. 


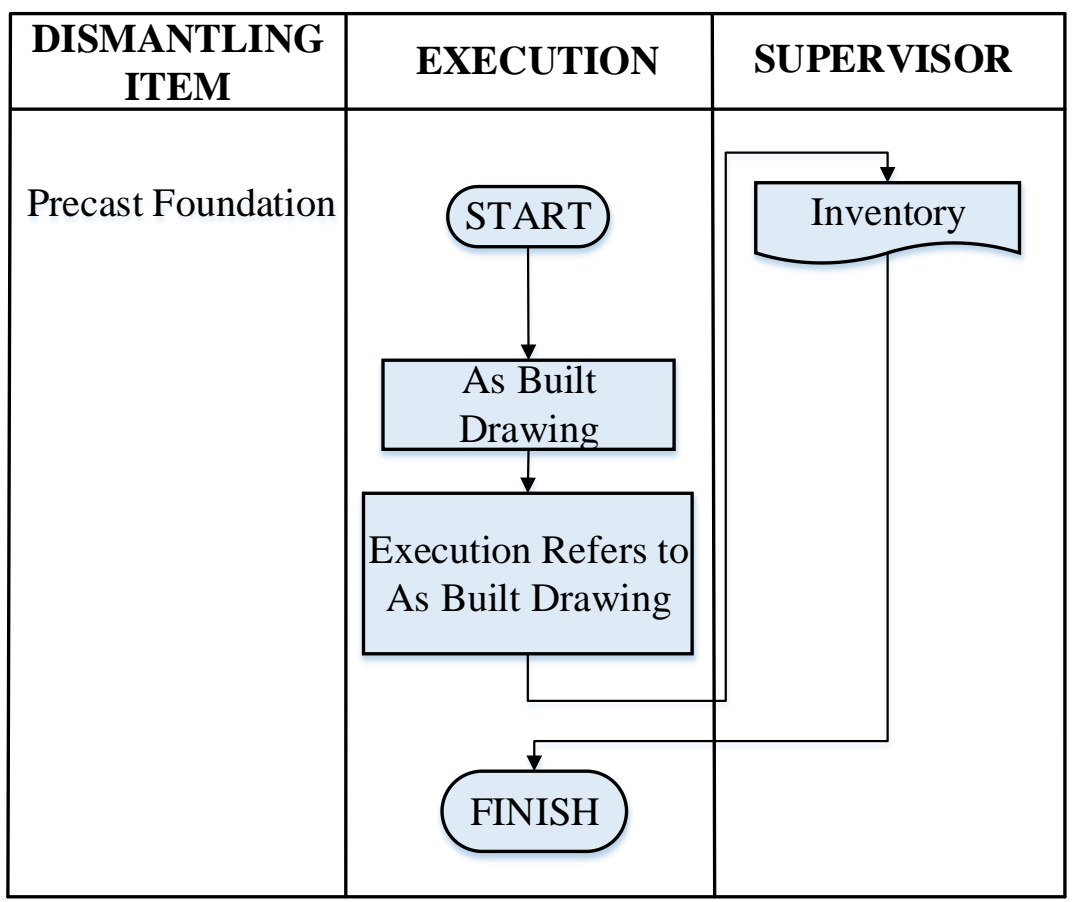

FIGURE 7. Uninstallations building flowchart for precast foundation.

\section{CONCLUSION}

The recommendation of portable building is using cold formed steel yield strength of 450/550 Mpa, Min tensile stress 450/550 Mpa, modulus of elasticity of 200,000 Mpa, and using Hot Dip Galvanized Z220 and Z275 stainless coating by P.E.B and GRC, seperated in the modular shape $9.6 \mathrm{~m} \times 4 \mathrm{~m}$ per modul. Adopted from FEMA 646, require more than 1 floor. Design is intended to minimize the risk of material loss, easy to move and uninstall (protable and knockdown), continuing tsunami load (tsunami friendly), eco friendly (zero waste), efficient cost and time, and does not require many workers (less workforce).

\section{REFERENCES}

A.W. Coburn, dkk. (1994). Mitigasi Bencana Edisi 2.UNDP

FEMA P646. (2008) Guidelines for Design of Structures for Vertical Evacuation from Tsunamis. Department of Security Homeland, U.S, 2-6.

G.A. Mcdonald, and F.P. Shepard. (1947). "The Tsunami of 1 April in the
Hawaiian Island 1946," Pacific Science, California.

Irwan, et al. (2016) "Bangunan Portabel sebagai Solusi Kebutuhan Hunian Temporer yang Layak Huni," Jurnal Sains dan Seni.

Koltermann, Peter. (2009). United Nations Office for Disaster Risk (UNDRR).

Marwasta, D., \& Priyono, K. D. (2016), Analisis Karakteristik Permukiman Desa-Desa Pesisir di Kabupaten Kulonprogo. In Forum Geografi, (5768).

McCormac, Jack C. (1981). Structural Steel Design, Third Edition. Harper \& Row Publisher, New York.

Nugraheni, et al. (2018). Recommendation of Semi-Permanent Buildings for Tsunami Prone Areas, World Academy of Science Engineering and Technology, Singapore.

Subrata. (2013). Pengenalan Teknologi Sistem RISHA, Presentation, PUSPERKIM Badan Litbang Kementrian PUPR. 
Zhao, Zianzhong. (2016). Basic Principles of Steel Structures, tersedia di http://www.sals.org.cn/teaching/zhaosir/int roduction-1.pdf.

AUTHORS:

Adwitya Bhaskara

Civil Engineering Program, Science Faculty and Technology, Universitas Teknologi Yogyakarta, Yogyakarta.

Email: adwitya.bhaskara@staff.uty.ac.id

Fitri Nugraheni

Program in Civil Engineering, Civil Engineering Faculty and Planning, Universitas Islam Indonesia, Yogyakarta.

Email: fitri.nugraheni@uii.ac.id

N. Faried Hanafi

Architects and Consulting Engineers, PT Pola

Data Consultant Yogyakarta, Yogyakarta.

Email:nfariedh@gmail.com 